\title{
THE HEDGING IMPACT TO FIRM VALUE OF PUBLIC COMPANIES IN INDONESIA
}

\author{
Arius Edwin*, Achsani Noer Azam, Bandono Bayu \\ School of Business, IPB University, Indonesia \\ *E-mail: edwin.arius@gmail.com
}

\begin{abstract}
The purpose of this study is to have comprehensive understanding of hedging implementation in the companies which are included in the LQ 45 Index and to comprehend the impact of hedging to the firm value. The data using secondary data which are annual report of public companies that consistently included in the LQ 45 Index on the Indonesian stock exchange for 2015-2018. The sampling technique is purposive sampling method, while the analysis technique is using data panel regression analysis. The finding show that companies which are included in LQ 45 index did hedging actvities to mitigate currency risk that may arise from long-term debt in foreign currencies such as loans with more than 1 year, bonds payable and cash flows. Furthermore, this research did not show that hedging could affect the firm value. Meanwhile, profit and dividend are factor that significantly influence the firm value.
\end{abstract}

\section{KEY WORDS}

Hedging, firm value, lq 45 index, panel data.

The rupiah currency is one of the currencies among several ASEAN countries which has high volatility. From 2015 to 2018 , the rupiah fluctuated by $10.89 \%$ in $2015,-2.60 \%$ in $2016,0.83 \%$ in 2017 and $6.89 \%$ in 2018 . The movement of the rupiah on January 2, 2015 still at the level of 12,474 then the value of the Rupiah continued to weaken, on January 4 , 2016 it was at the level of 13,898 or decreased by approximately $11 \%$ within one year. A decrease of $11 \%$ within 1 year is a significant decrease. The rupiah depreciation may continue if macro and micro economic conditions in Indonesia do not improve.

In order to mitigate risk due to currency volatility, the alternative is to use hedging. The use of hedging is very important considering Indonesia's previous experience when it suffered financial crisis in 1998 where many private foreign debts did not hedge so that the foreign debt burden of private companies in foreign currencies swelled when there was a depreciation of the rupiah exchange rate which resulted a default on the debtor's side. Hedging is a reduction in an existing risk by eliminating exposure to price movements in an asset (Goyal 2009). Based on several studies, it is known that hedging has a certain impact on the company both positively and negatively, including the research of Allayannis (1996) where the use of currency derivatives has a positive effect on firm value. Hedging foreign currency and interest rates increase the value of firms significantly in the UK (Belghitar et al. 2008). The use of derivatives in foreign currencies has a significant effect on firm value (Clark and Mefteh 2010). Several types of hedging can reduce certain risks which in turn lead to value creation and hedging increases firm value. (Nova et al. 2015). However, hedging can have a negative impact on the company. This is reflected in research by Fauver (2000) where the use of derivatives has a negative impact on companies that have business diversification. Hedging does not affect firm value (Jin and Jorion 2006). As well as research by Guo (2013) where when interest rates rise and are volatile, hedging can cause unexpected interest rate losses and lower financial performance of REIT (Real Estate Investment Trust).

In the capital market there are many companies that investors could choose for their investment activities, including company stocks that are included in the LQ 45 index. According to the Indonesian Stock Exchange (BEI 2019) the LQ 45 Index is an index that measures the price performance of 45 stocks that have high liquidity, large market capitalization and supported by good company fundamentals. Meanwhile, LQ 45 stocks are 
stocks that have a high level of liquidity (are often traded), have a large market capitalization (able to represent the market) and are classified as the best choice of stocks, so they are attractive to be the population in this study. In addition, companies stock that are included in the LQ 45 index are in great demand by investors, so that company information included in the LQ 45 index will be very much needed by investors for consideration in making stock investment decisions (Wulandari et al. 2016).

In analyzing the impact of hedging, companies usually do the hedging due to a gap between assets in foreign currency and liabilities in foreign currency and theoretically hedging can mitigate the currency risk. Based on the above reasons, this research wants to know the implementation of hedging in public companies and the impact of hedging to the firm value of companies which are listed on the LQ 45 Index. Meanwhile, the LQ 45 Index is widely used by investors as a reference before investing in the stock market.

\section{LITERATURE REVIEW}

One strategy for managing currency risk is hedging. Eiteman et al. (2013) states that hedging is taking a good position because it obtains cash flow from assets to contracts including forward contracts whose value can go up or down and there will be an offset in the form of a decrease or increase in the value of the position that has been taken. The next theory from Jin and Jorion (2006) which states that hedging is a way to reduce existing risk by eliminating exposure to price movements on an asset. In this research, the hedging activities uses a dummy variable with a value of ' 1 ' if the company is hedging and ' 0 ' is not hedging.

Apart from hedging, there are 6 other factors that influence firm value. According to Winarto (2015) the factors that affect firm value are firm size, profitability, leverage, dividends, growth and liquidity.

Belghitar et al. (2008) stated that the investment costs of a larger company are relatively lower compared to smaller companies because larger companies have more information to obtain outside funding and have better access to the capital market and have more capacity to obtain credit. The lower relative investment cost of the company will save the company's cash flows and will increase the firm's value. Based on research from Allayannis and Weston (2001), Jin et al (2006), Gonzalez et al (2013) and Ahmed et al (2014), this study uses a proxy log of total assets as a proxy model to measure firm size.

$$
\text { Firm Size }=\text { Ln(Assets })
$$

Companies that have large profits will be purchased at a premium price compared to companies with low profits. This shows that the value of the company is higher than the others. (Allayannis and Weston 2001; Jin and Jorion 2006; Junior and Laham 2008). In assessing this profitability, the Return on Assets (ROA) indicator is used, which is the ratio of net income to total assets.

$$
R O A=\frac{\text { Earnings Before Interest and Taxes }}{\text { Total Assets }}
$$

Belghitar et al. (2008) stated that when the company's long-term debt increases, the costs borne by the company for obtaining outside funding also increases. Companies that have large debts will try to prevent the company from bearing exchange rate risk by hedging. Based on research from Jin and Jorion (2006) and Junior and Laham (2008) Leverage is defined as long-term foreign currency debt divided by total assets.

$$
\text { Leverage }=\frac{\text { Book Value of Long Term Debts }}{\text { Total Assets }}
$$

Dividends based on research by Allayannis and Weston (2001) and Jin and Jorion (2006) are a proxy for company access to financial markets. If the company distributes 
dividends, it can have an effect on capital, which in turn can lead to lower Tobin's $Q$ value (Allayannis and Weston 2001). In this research, the dividend activities uses a dummy variable with a value of " 1 " if the company makes dividend payments and "0" does not pay dividends.

To assess the growth (growth) of a company, the company will assess the level of investment (capital expenditure). This is because the company's investment in assets can produce products to sell. The amount of product sold will determine the value of the firm, so the capital expenditure variable is also a variable whose impact is analyzed on firm value. Growth can be formulated as follows:

$$
\text { Growth }=\frac{\text { Capital expenditures }}{\text { Total Sales }}
$$

Belghitar et al. (2008) stated that companies that have cash constraints have higher Tobin's $Q$ because these companies have the possibility to invest dominantly in projects that have positive NPV. Meanwhile, companies with more free cash flow will invest in projects with negative NPV. Thus, the quick ratio variable can know its impact on positive or negative project NPV or firm value. Liquidity can be formulated as follows:

$$
\text { Quick Ratio }=\frac{\text { Current Assets }}{\text { Current Liabilities }}
$$

Damodaran (2014) states that company value or firm value is the value of cash and other non operating assets plus operating assets or debt plus equity. In this study, the dependent variable is the firm value represented by Tobin's $Q$. This is consistent with research conducted by Allayannis and Weston (2001) and Nova et al. (2015). Tobin's Q value is calculated using the formula In (natural logarithm) of the ratio of market value of assets divided by book value of assets, because In shows the growth rate or shows the geometric rate of growth of the ratio of market value of assets divided by book value of assets. The greater the value of In (Tobin's Q), the higher the firm value. According to Allyannis (2011) and Ahmed et al (2014), the asset market value is obtained from the following calculations:

$$
\text { Market Value of Asset }=\frac{\text { Total Assets }- \text { Book value of Equity }+ \text { Market Value of Equity }}{\text { The Book value of Asset }}
$$

\section{METHODS OF RESEARCH}

This study uses secondary data which are the annual financial statements of public companies listed in the LQ 45 Index on the Indonesia Stock Exchange (BEI) from 2015 to 2018 which consistently doing hedge or not. The data is taken from the IDX website at http://www.idx.co.id. The sampling method used is purposive non-probability sampling and the analytical methods in this study is a panel data regression analysis.

The regression equation model used in this study adopts the theory of Gujarati and Porter (2009) and Nguyen (2015) where the models used is:

Value $_{i t}=\alpha_{i}+\beta_{1} *$ profit $_{i t}+\beta_{2} *$ size $_{i t}+\beta_{3} *$ capex $_{i t}+\beta_{4} *$ leverage $_{i t}+\beta_{5} *$ dividen $_{i t}+\beta_{6} *$ liquidity $_{i t}+\beta_{7} *$ hedging $_{i t}+\varepsilon_{i t}$

Where: Value $_{i t}$ (the ratio of firm value represented by Tobin's Q); $\alpha_{i}$ (constant); $\varepsilon_{i t}$ (Regression Error).

\section{RESULTS OF STUDY}

In panel data regression analysis, the best model was chosen based on the Chow test, Hausman test and Lagrange test. Three alternative approaches to processing methods are common effect (CE) / Pooled Least Square (PLS), fixed effect (FE) and random effect (RE). 
Table 1 - Comparison Results of Panel Data Regression Model Determination

\begin{tabular}{|c|c|c|c|}
\hline Testing Type & Basic Decision Making & Result & Conclusion \\
\hline Chow Test & $\begin{array}{l}\text { If (Prob.) for Cross-section F. }>0.05, \text { CE } \\
\text { is chosen } \\
\text { If (Prob.) for Cross-section F. }<0.05, \mathrm{FE} \\
\text { is chosen }\end{array}$ & $\begin{array}{l}\text { (Prob.) for Cross-section F. }=0,0000 \\
<\alpha(0.05)\end{array}$ & FE is chosen \\
\hline Hausman Test & $\begin{array}{l}\text { If (Prob.) for Cross-section random > } \\
0.05, \mathrm{RE} \text { is chosen. } \\
\text { If (Prob.) for Cross-section random < } \\
0.05, \mathrm{FE} \text { is chosen }\end{array}$ & $\begin{array}{l}\text { (Prob.) for Cross-section random }= \\
0.1404)>\alpha(0.05)\end{array}$ & $R E$ is chosen \\
\hline $\begin{array}{l}\text { Langrange Multiplier } \\
\text { (LM) Test }\end{array}$ & $\begin{array}{l}\text { If } p \text {-value }>\alpha(0.05), \mathrm{CE} \text { is chosen } \\
\text { If } p \text {-value }<\alpha(0.05), \mathrm{RE} \text { is chosen }\end{array}$ & $p$-value $=0.0000<\alpha(0.05)$ & $\mathrm{RE}$ is chosen \\
\hline
\end{tabular}

Source: Result of Output Eviews 9, 2019.

From determining the panel data regression model above, it is found that the best model is the Random Effect. At the same time, this research has fulfilled all of classical assumption tests which are normality test, multicollinearity test, autocorrelation test and heteroscedasticity test.

Table 2 - Result of $t$ test

\begin{tabular}{llll}
\hline Variable & Coefficient & t-Statistic & Prob. \\
\hline C & 4.689347 & 1.843915 & 0.0689 \\
Profit & 3.251014 & 6.543967 & 0.0000 \\
Size & -0.153422 & -1.913260 & 0.0593 \\
Capex & 0.373319 & 1.143669 & 0.2562 \\
Leverage & -0.369256 & -0.670786 & 0.5043 \\
Dividend & 0.234940 & 2.842947 & 0.0057 \\
Liquidity & 0.006608 & 0.180614 & 0.8571 \\
Hedging & -0.129170 & -1.069825 & 0.2879 \\
& & & \\
R-squared & & 0.496605 & \\
Adjusted R-squared & & 0.452558 & \\
F-statistic & & 11.27442 & \\
Prob(F-statistic) & & 0.000000 & \\
\hline
\end{tabular}

Source: Result of Output Eviews 9, 2019.

The $\mathrm{t}$ statistic test shows how far the influence of one independent variable (profitability, firm size, capex, leverage, dividends, liquidity and hedging) partially or individually has a significant effect on the dependent variable (firm value).

Effect of profitability to the firm value. Based on the results of the t test, it is known that profit has a significance value of 0.0000 smaller than 0.05 (or t-count $=6.543967$ is greater than the t-table value $=2,000$ ), which means that profit has an effect on firm value (Tobin's Q). This is consistent with various studies in Indonesia related to company value where the greater the profit, the higher the company value (Hermuningsih 2013; Winarto 2015 and Ahmad 2016). The results of this study are also in line with research conducted by Nguyen (2015) where profitability has a positive effect on the value of companies listed on the Stockholm Stock Exchange in the period 2005-2010. The same result also occurs in a study conducted by Naito and Laux (2011) where profitability has a positive and significant effect on the value of companies listed on the S\&P 500 Index in America.

Effect of firm size to the firm value. From the results of the t test it is known that the firm size has a significance value of 0.0593 greater than 0.05 (or $\mathrm{t}$-count $=-1.913260$ which is absolutely less than the value of t-table $=2,000$ ) which means that the firm size is not affect firm value (Tobin's $Q$ ). The research results prove that firm size has no effect on firm value. This is not in line with research by Nguyen (2015) and Ahmad (2016) where firm size has an effect on firm value. However, there are other studies in Indonesia related to firm value where firm size does not affect firm value as was done by Winarto (2015). Researchers opines that the negative relationship to firm value is related to the increase in leverage or 
long-term debt by the company to increase the size of the company so that there is an increase in the company's liabilities which is getting bigger, which in turn reduces the company value.

Effect of growth (capital expenditure) to the firm value. Referring to the results of the $t$ test, it is known that growth (capital expenditure) has a significance value of 0.2562 greater than 0.05 (or t-count $=1.143669$ is smaller than the t-table value $=2,000$ ) which means that growth (capital expenditure) has no effect on firm value (Tobin's $Q$ ). The results of this study are in accordance with the results of research conducted by Naito and Laux (2011), Nguyen (2015) and Ahmad (2016) which state that growth (capital expenditure) has no significant effect on Tobin's Q. However, this is contrary to other studies in Indonesia conducted by Hermuningsih (2013) and Winarto (2015) related to company value where the greater the growth (capital expenditure) becoming higher on the company value. However, considering that the effect in this study is not significant, it cannot be generalized.

Effect of leverage to the firm value. Based on the results of the t test it is known that leverage has a significance value of 0.5043 greater than 0.05 (or t-count $=-0.670786$ which is absolutely less than the t-table value $=2,000$ ) means that leverage has no effect on firm value (Tobin's Q). This is in line with the research of Naito and Laux (2011), Nguyen (2015), Ahmad (2016) which state that leverage does not affect firm value and has a negative relationship. The researcher considers that the companies included in the LQ 45 Index tend to be capital intensive, the higher the foreign currency debt they have, the greater the costs that must be borne by the company considering that the company's revenue tends to be in Rupiah. These costs will increase if the value of the Rupiah depreciates against foreign currencies. This causes a negative leverage effect on firm value.

Effect of dividend to the firm value. From the results of the test it is known that dividend has a significance value of 0.0057 less than 0.05 (or t-count $=2.842947$ greater than the t-table value $=2,000$ ) means that dividends have an effect on firm value (Tobin's $Q$ ). The results of this study are in line with research conducted by Nguyen (2015) and Winarto (2015) which states that dividends have a significant and positive effect on firm value. On the other hand, the results of this study are not in line with research conducted by Naito and Laux (2011) where dividend payments actually have a negative and significant effect on firm value on the S\&P 500 Index in America. This study suspects that investors in America do not see dividend payments as a sign that the company's management has run the company well, otherwise dividend payments will signal a lack of opportunity to invest in the company in the future. However, in research conducted on the Indonesia Stock Exchange, especially on the LQ 45 Index, researchers argue that along with the increasing level of company profitability, companies tend to distribute dividends to their shareholders. More than that, a public company that also distributes dividends can be seen as a good and prospective company from an investor's point of view.

Effect of liquidity to the firm value. Referring to the results of the test, it is known that liquidity has a significance value of 0.8571 greater than 0.05 (or t-count $=0.180614$ smaller than the t-table value $=2,000$ ) which means that liquidity has no effect on firm value (Tobin's Q). The results of this study are not in line with other research in Indonesia which states that liquidity has a significant and negative effect on firm value (Winarto 2015) and (Ahmad 2016). This is due to the opinion that the greater the liquidity value of the company, the company can allocate cash funds to buy productive assets as well as the opportunity to invest in various portfolios to increase company value.

Effect of hedging to the firm value. Based on the results of the t test it is known that hedging has a significance value of 0.2879 greater than 0.05 (or t-count $=-1.069825$ which is absolutely smaller than the $t$-table value $=2,000$ ) means that hedging has no effect on firm value (Tobin's Q). The results of this study are in line with previous research which states that hedging does not add value to the company (Guo 2013; Bashir 2013; Nguyen 2015). Moreover, the results of research conducted by Bashir (2013) show that the use of hedging has a negative but insignificant impact on firm value. This study contradicts the research of Allayanis (2001) which shows that hedging can increase firm value. The negative impact was caused by 2 factors, which are the price of the hedging product / premium which was 
expensive and the limited counterparty banks that could serve the company's hedging needs. The first factor is the expensive price of hedging products, especially compared to other hedging products. The price that is quite expensive can result in higher hedging costs, especially if the company is hedging in a large amount. Another factor is that not many banks provide hedging products. Currently, there are 110 commercial banks in Indonesia, but based on Bank Indonesia and Financial Service Authority (OJK) regulations, only banks with large core capital (above 5 trillion rupiah), namely BUKU 3 and BUKU 4, are allowed to conduct hedging transactions, of which only 32 banks.

\section{CONCLUSION}

Public companies which are included in the LQ 45 index and consistently doing hedging for the period 2015 to 2018 did hedging activities to mitigate currency risk that may arise from long-term debt in foreign currencies such as loans with more than 1 year, bonds payable and cash flows. Based on the results of research on 7 factors that affect firm value, which are profitability, firm size, growth, leverage, dividends, liquidity and hedging, it turns out that only 2 factors have a significant influence on firm value that are profitability and dividends which both have a positive effect. Researchers also analyzed hedging as one of the factors that affect firm value, but in this research, hedging did not affect the public company's firm value.

\section{REFERENCES}

1. Ahmad B. (2016). Analisis dampak hedging terhadap nilai perusahaan telekomunikasi publik di Indonesia. Thesis. Program Magister Manajemen Bisnis. Institut Pertanian Bogor.

2. Ahmed H, Azevedo A, Guney Y. The effect of Hedging on Firm Value and Performance: Evidence from the Nonfinancial UK Firms; Annual Meeting; 25-28 June 2014; Rome, Italy. Rome (IT): European Financial Management Association.

3. Allayannis G. (1996). Exchange rates, hedging, and the value of the firm. Dissertation. New York (US): School of Business of New York University.

4. Allayannis G, Weston J. (2001). The use of foreign currency derivative and firm market value. The Review of Financial Studies. 14(10): 243-276.

5. Bashir H. (2013). Impact of derivatives usage on firm value: evidence from non financial firms of Pakistan. Journal of Management Research. 5(4): 108-127.

6. [BEI] Bursa Efek Indonesia. (2019). Jenis Indeks. Jakarta (ID): Bursa Efek Indonesia

7. Belghitar Y, Clark E, Judge A. (2008). The value effects of foreign currency and interest rate hedging: the UK evidence. International Journal of Business. 13(1): 44-60.

8. Clark E, Mefteh S. (2010). Foreign currency derivatives use, firm value and the effect of the exposure profile: evidence from France. International Journal of Business. 15(2): 184196.

9. Damodaran A. (2014). Applied Corporate Finance. $4^{\text {th }}$ ed. New York (US): John Wiley \& Sons. Inc.

10. Eiteman DK, Stonehill AI, Moffet MH. (2013). Multinational Business Finance. $13^{\text {th }}$ edition. New York (US): Pearson. Inc.

11. Fauver LA. (2000). Diversification, derivative usage, and firm value [dissertation] Florida (US): University of Florida.

12. Gonzalez PF, Yun H (2013). Risk management and firm value: evidence from weather derivatives. The Journal of Finance. 68 (7): 2143-2176.

13. Goyal A. (2009). The Princeton Encyclopedia of the World Economy. Vol 1. Princeton (US): Princeton University Press.

14. Gujarati DN, Porter DC. (2009). Basic Econometric. $5^{\text {th }}$ ed. New York (US): Mc-Graw Hill International Edition. 
15. Guo X. (2013). How does the use of derivatives affect investment performance, risk, and firm value? evidence from the U.S. real estate investment trust (REIT) industry [dissertation]. Delaware (US): University of Delaware.

16. Hermuningsih, S. (2013). Pengaruh profitabilitas, growth opportunity, struktur modal terhadap nilai perusahaan pada perusahaan publik di Indonesia. Buletin Ekonomi Moneter and Perbankan. Oktober: 128-148.

17. Jin Y, Jorion P. (2006). Firm value and hedging: evidence from U.S. oil and gas producers. The Journal of Finance. 61(2): 893-920.

18. Junior R J, Laham J. (2008). The impact of hedging on firm value: evidence from Brazil. Journal of International Finance and Economics. 8 (5): 76-91.

19. Naito J, Laux J. (2011). Derivative usage: value-adding or destroying. Journal of Business \& Economic Research 9(11): 41-50.

20. Nguyen N. (2015). Does Hedging Increase Firm Value? An examination of Swedish Companies Thesis. Lund (SE): Lund University.

21. Nova M, Cerqueira A, Brandao E. (2015). Hedging with derivatives and firm value; evidence for the non financial firms listed on the London Stock Exchange. FEP Working Paper. 568.

22. Winarto J. (2015). The determinants of manufacturing firm value in Indonesia stock exchange. International Journal of Information, Business and Management. 7(4): 323349.

23. Wulandari OS, Rahayu SM, Nuzula NF. (2016). Analisis fundamental menggunakan pendekatan price earnings ratio untuk menilai harga intrinsik saham untuk pengambilan keputusan investasi saham (studi pada perusahaan yang sahamnya masuk indeks LQ45 periode tahun 2010-2012 di bursa efek Indonesia). Jurnal Administrasi Bisnis (JAB). Vol. 23 No. 1: 73-80. 